\title{
ПОСТРОЕНИЕ МЕЖСУБЪЕКТНЫХ ВЗАИМООТНОШЕНИЙ В СИСТЕМЕ "УЧИТЕЛЬ-УЧЕНИК" - ОСНОВА ДИФФЕРЕНЦИАЦИИ ОБРАЗОВАТЕЛЬНОГО ПРОЦЕССА РАЗВИВАЮЩЕЙСЯ ШКОЛЫ
}

\author{
Волкова Анна Александровна \\ Платонова Анна Александровна \\ MOУ СОШ №2
}

\begin{abstract}
Аннотация. Изменяющиеся социально-экономические условия развития общества определили характер парадигмы современной педагогической системы, особенностью которой является самостоятельность в осмыслении и в создании педагогического опыта, ориентация субъектов деятельности на творческий поиск.
\end{abstract}

Ключевые слова. Творчество, рефлексия, личность-ориентированное обучение, модели дифференцированного обучения.

\section{BUILDING INTER-SUBJECT RELATIONSHIPS IN THE "TEACHER - STUDENT" SYSTEM IS THE BASIS FOR DIFFERENTIATING THE EDUCATIONAL PROCESS IN A DEVELOPING SCHOOL}

\section{Volkova Anna A. Platonova Anna Aleksandrovna}

\begin{abstract}
The changing socio-economic conditions of society's development have determined the nature of the paradigm of the modern pedagogical system, which is characterized by independence in understanding and creating pedagogical experience, and the orientation of subjects to creative search.
\end{abstract}

Key words: creativity, reflection, personality-oriented learning, differentiated learning models. 
"Признание ученика главной действующей фигурой всего образовательного процесса и есть личностно-ориентированная педагогика, где во главу угла становится личность” И. С. Якиманская

Изменяющиеся социально-экономические условия развития общества определили характер парадигмы современной педагогической системы, особенностью которой является самостоятельность в осмыслении и в создании педагогического опыта, ориентация субъектов деятельности на творческий поиск.

Проблема дифференцированного обучения не является новой для отечественной и зарубежной педагогической науки и практики

Дифференцированное обучение и воспитание в подлинном смысле приоритет личностно развивающей школы, в которой воспитательная деятельность становится ведущей функцией. Такое учебно-воспитательное учреждение предоставляет воспитаннику возможности для формирования способности к смыслопоиску, творчеству, рефлексии; волевой регуляции, самостоятельности, ответственности и других важных качеств. Главная цель личностно развивающей школы - способствовать обретению школьником личностного нравственного опыта, становлению жизненного социального и профессионального самоопределения.

В личностно развивающей школе образовательный процесс предстает как деятельность, в которой особая роль принадлежит педагогической поддержке и помощи в сфере самоорганизации и самоутверждения личности.

Гуманистическая парадигма данной системы состоит, на наш взгляд, в том, что человеку как носителю природных ценностей дается возможность самореализации: школа предоставляет личности образовательные услуги, а личность выбирает собственную траекторию образования.

Реализация индивидуального подхода в обучении позволяет в результате всестороннего изучения своих воспитанников создать представление о характере каждого из них, о его интересах, способностях; о влиянии на него семьи и ближайшего окружения; получить возможность объяснить поступок и отношение к учебе в целом.

В дидактике нет готовых рецептов на все случаи жизни по реализации данного принципа, т. к. сама проблема индивидуального подхода в обучении носит творческий характер. 
При внедрении дифференцированного обучения необходимо создать условия его осуществления:

- глубокое изучение индивидуальных и типологических особенностей учащихся и групп учащихся;

- умение анализировать учебный материал, выделять возможные трудности, с которыми встретятся разные группы учащихся;

- составление технологической карты, включая вопросы разным группам и отдельным учащимся;

- умение “спрограммировать” обучение разных групп учащихся (в идеале каждого ученика);

- организация учебного процесса, предоставляющая ученику возможность выбирать его содержание, вид, форму при выполнении заданий, решении задач;

- осуществление оперативной обратной связи, создание такой атмосферы на уроке (взаимоотношения учителя и ученика), которая расковывает учащихся;

- создание мотивации успешности учения;

- активное стимулирование ученика к образовательной деятельности, содержание и формы которой должны обеспечивать ученику возможность самообразования, саморазвития, самовыражения в ходе овладения знаниями;

- выявление и оценка способов учебной работы;

- обеспечение контроля и оценки не только результата, но и процесса учения.

Анализ литературы и периодики позволяет выделить 4 уровневые модели дифференцированного обучения в системе “Учитель- ученик” :

1. Манипулятивный. Данная группа педагогов характеризуется тем, что взрослый использует ребёнка как средство для достижения собственных целей. Ученик- объект, принимает указания, рекомендации, команды беспрекословно, не задумывается о выполнении. Ребёнок безынициативен, занимает репродуктивную позицию, присваивает чужую точку зрения в готовом виде. Для развития конкурентоспособной, мобильной личности, способной решать творческие задачи в данном случае не возможности, поскольку ученик воспринимается не просто как объект, а как беспрекословный исполнитель. К сожалению, иногда мы вынуждены наблюдать тотальное управление, где ребёнок- средство этого управления, зачастую учителя- манипуляторы осознанно манипулируют, что приводит к 
искажениям в развитии личности. (Я знаю, как им управлять!- говорит педагог).

2. Следующая уровневая модель восприятия и общения “Рефлексивная игра”. В данном случае ученик воспринимается как объект, как средство для достижения педагогических целей. Учитель понимает, что от ученика пользы мало, поскольку ученик ждёт внешних воздействий. Развитие почти не проявляется. Всё берёт на себя учитель: инициативу, ответственность и т.д. в процессе взаимодействия, раскрыв каждого, учитель выделяет то, что для него важно и отвечает его интересам и ценностям и приводит к тому, чтобы ученики приняли его точку зрения..

3. “Деловое общение”. Данная уровневая модель восприятия и общения предполагает, что учитель понимает, что урок - это не односторонний процесс передачи информации от субъекта к объекту, а процесс совместной деятельности, в которой все участники процесса в равноценной, равнонеобходимой, равноактивной позиции. Ученик воспринимается как равноценный партнёр, только при участии которого урок может состояться, в результате рождаются сооценки, соанализы, соавторство и.т.Д.. здесь нет победителей и побеждённых. Даётся право каждому. Ученик воспринимается не как средство, а как цель достижений деловых решений педагога. Ребёнок- ценность, незаменимая на данном участке работы. Результата совместной деятельности при этом формируется и появляется на уроке. До урока нет, только общая схема. Ученики полностью привлекаются для получения общего продукта - урока. Такое восприятие ученика ставит его в позицию учителя. “Дети мои учителя”,- говорил Аманошвили, поскольку они учат каким способом их учить и побуждают учителя изыскивать новые средства педагогической деятельности.

4. “Духовное общение”. Включает в себя все особенности предыдущего, но если на 3 уровне ученик и учитель- это деловые партнёры, которые относятся друг к другу с уважением, стремятся к более высокому результату совместной деятельности, понимают, что он зависит от вклада каждого из них, то в дальнейшем опыт наработок переходит эволюционно на уровень духовного единения (Сухомлинский, Амонашвили, Горшкова и.др.) педагог и ученик в данном случае несомненно - субъекты общения и восприятия, стремятся друг к другу не только на деловой, но и личностной основе, тем самым обогащая деловое общение. В данном случае выйти за пределы восприятия ученика как делового партнёра - значит обогатиться. Учитель ученику не нужен как учитель, но нужен как человек. Лучший 
педагог тот, кто умеет учиться у своих учеников. в таком взаимодействии субъектов лучшими учениками становятся не те, кто идёт вслед учителю, а те, кто с помощью педагога находят свой собственный, а значит единственно верный путь.

И если современный ученик является равноценным, равнозначным субъектом, у которого хочется приобщиться, присвоить ценности, то у педагога формируется потребность диагностировать происходящие в ученике и в нём самом изменения. Именно в этом случае методы педагогической диагностики (наблюдение, беседы, анкеты, опросники, которые встроены в деятельность) будут выполнять не только функцию методов, но, и станут средством самосовершенствования педагогической деятельности. Поскольку поставить новую цель грамотный педагог сможет только в результате диагностики, а данные которые он получит в результате исследования - это средство постановки цели.

Построение педагогом дифференцированного обучения в современной развивающейся школе требует применения межсубъектных технологий обучения и воспитания, главные принципы которых:

- равноценное, равноактивное, равносвободное и равноуникальное участие всех субъектов, пари этом ученики воспринимаются не в ролевом, статусе, а в субъектном. Это возможно при соблюдении второго принципа

- принципа равенства, что даёт возможность всех делать принципиально равными по отношению к тому, что делается, не зависимо от статуса, опыта, возраста. В данном случае речь идёт о социально-смысловом равенстве (любой ребёнок - ценность), равенстве прав на участие;

- равноценное распределение ответственности. Равноценность проявляется в формулировании задач, корректировке способов решения, где каждый имеет право внести свои изменения, в оценке решения, в анализе результата, в праве предложить новую цель или ход действий.

Таким образом, истинная дифференциация обучения требует от педагога применения межсубъектных технологий, духовная ценность которых заключается, прежде всего, в изменении взгляда на ученика, который является не только “ученическим человеком” (Ананьев Б.Г.), но и полноценной человеческой личностью.

Обращение к ученику как к человеку, создание условий для развития естественных диалоговых и человеческих отношений, “очеловечивание" содержания обучения и воспитания развивают гуманитарный тип мышления учителя и способствуют инновационному преобразованию школы в целом. 
Основу нестандартных технологий диалогического взаимодействия составляет общение как ценность, как творчество, как совместный поиск истины педагогом и учащимися на уроке. Опыт последних лет доказывает, что проектирование уроков с диалогической направленностью позволяет преодолеть излишнюю декларативность и односторонность в содержании обучения, а также формализм и неестественность в отношениях учителя и учащихся.

Использование межсубъектных технологий диалога помогает человеку стать тем, кем он может и способен стать. Философия педагогического действия в данном случае максимально раскрепощает личность, освобождает ее от условностей, ограничений, шаблонов, требует создания условий, оптимально способствующих индивидуальной самореализации учащихся.

Предлагаемые инновационные модели диалоговых технологий обучения, как целостно, так и фрагментарно, могут быть использованы в образовательном процессе. Они так же могут служить своеобразной точкой отсчета для создания других (авторских) моделей диалогического взаимодействия субъектов.

Модель урока - урок свободного общения.

Гуманитарная сила этих уроков развивается благодаря непрерывному разговору и свободному общению ученика с книгой, сверстниками, учителем.

\section{Модель урока - урок-исследование.}

Данный урок может проектироваться на различном содержательном материале: литературно-поэтическом, естественно-научном и др. Это может быть и анализ поэтических произведений в среднем звене школы, и исследование текста литературного произведения в старших классах.

\section{Модель урока - урок-встреча.}

На уроки-встречи могут быть приглашены люди науки, искусства, просвещения, производства, участники войны, известные люди города, а также родители, близкие учащихся. Важное условие организации такого урока - его идея должна исходить от самих учащихся.

\section{Модель урока - урок вопросов учителю.}

Главное назначение таких уроков или фрагментов уроков в том, чтобы учить учащихся не только отвечать на вопросы, но, главное, учить задавать и формулировать вопросы. Поощрением за интересный вопрос учитель стимулирует познавательную активность и субъектную позицию школьника.

\section{Модель урока - урок-конференция.}


В зависимости от интересов и увлечений школьников учитель предлагает им подготовить доклады или сообщения на урок, исходя из индивидуальных способностей и расположенности к какому-то виду деятельности.

\section{Модель урока - урок спора с учителем.}

Задачи данного урока: - побуждать учащихся к аргументированному, логическому, доказательному спору; - способствовать развитию потребности переживать радость познания истины.

\section{Модель урока - урок разговора с самим собой.}

Модель урока-разговора с самим собой направлена на развитие процессов самообщения, внутреннего диалога, внутренней речи, а также на предоставление школьникам широких возможностей письменно рассказывать о своих впечатлениях, мыслях, чувствах, переживаниях, отношениях и оценках.

Гуманистическая позиция педагога заключается в том, что он принимает ученика одновременно таким, каков он есть, и каким он может и должен стать. Тогда новое информационное пространство межсубъектных технологий диалога включается в структуру жизнедеятельности личности. А личность, полноценно “проживая" единение с учителем, сверстниками, окружающей атмосферой, диалогически общается с жизнью, находясь одновременно в реальном и опережающем процессах саморазвития.

Таким образом, приоритет интересов человеческой личности предполагает создание личностно ориентированных моделей обучения и воспитания, то есть осознанно развиваемой педагогическим коллективом личности ученика, обладающего желаниями и потребностями, чувствами, собственным внутренним потенциалом саморазвития и самоорганизации, собственным темпом созревания и развития. В связи с этим реальная включенность педагогов в творческий процесс педагогического проектирования и реализации учебно-воспитательных задач на современном уровне требует иных профессиональных психологических позиции, радикальной переориентации школы на создание педагогической среды, способствующей наиболее полной актуализации творческих потенциалов личности педагога и ученика.

А.А. Волкова, А.А. Платонова, 2020 